\title{
AN ATTEMPT TO DETERMINE THE IMPACT OF ENERGY INTENSITY ON THE MARKET VALUE OF RESIDENTIAL UNITS ON THE EXAMPLE OF SELECTED BUILDINGS IN SZCZECIN
}

\author{
Iwona Foryś \\ Wydziat Nauk Ekonomicznych i Zarzadzania \\ University of Szczecin \\ e-mail:forys@wneiz.pl \\ Ewa Putek-Szeląg \\ Wydziat Nauk Ekonomicznych i Zarzadzania \\ University of Szczecin \\ e-mail:ewaputek@gmail.com
}

\section{Beata Ziembicka \\ University of Szczecin \\ e-mail: operaty@wp.pl}

Environmental requirements, constantly increasing energy prices as well as energy consumption by residential units and buildings have become an important factor in the decision-making processes in the real estate market. The preferences of residential unit buyers who recognize the problem of energy intensity and translate it into the transaction price have also been changing. However, amendments to the Act on real estate management and new European standards have imposed an obligation to include the certificates of energy performance of buildings and premises on real estate valuers in the valuation process. In this paper, energy intensity understood as the heating requirements of multifamily residential buildings is the basis for assessing the impact of the proposed variants on the market value of residential units. The paper analyzes the energy intensity of various types of buildings (e.g. in low and high buildings) and its impact on the market value of residential units in a selected housing estate in Szczecin, when the property valuer has access to energy performance certificates of neither the unit under valuation nor the units selected for comparison. The purpose of this study is to identify the relationship between the energy intensity and the market value of residential units. The proposed three models of real estate market value: non-classical, multiple regression and average price adjustment taking into account energy intensity, obtain results consistent with the actual transaction price at a satisfactory level. The assessment was made using standard deviation, a coefficient of variation and the average error of forecasts.

Keywords: real estate value modelling, real estate market analysis, energy intensity, market value.

JEL Classification: $R 31$.

Citation: Foryś, I., Putek-Szeląg, E. \& Ziembicka, E. (2020). An attempt to determine the impact of energy intensity on the market value of residential units on the example of selected buildings in Szczecin. Real Estate Management and Valuation, 28(1), 64-79.

DOI: https://doi.org/10.2478/remav-2020-0006 


\section{Introduction}

In the era of energy conservation which results from environmental requirements as well as from increasingly high energy prices, the preferences of residential property buyers are changing (Xie, 2018; Zheng et al., 2014). In addition, the implementation of EU directives to national regulations imposes, on member states, an obligation to monitor energy efficiency in every sector of their economy, including the construction industry. There have also been changes in the provisions of the Act on Real Estate Management, which imposed the obligation to take into account the energy performance certificates for buildings and premises in the valuation process on the professional group of property valuers.

The housing sector consumes almost $25 \%$ of final energy (e.g. for heating and living purposes, i.e. heating water or cooking) in the European Union (Dzieżyc et al., 2018). The level of energy consumption by households is affected primarily by climatic conditions, the economic situation of the country, socio-cultural conditions, the level of wealth of the population, the size of a residential unit, the average number of occupants and the energy performance of a block of flats (Kazak, 2018). Therefore, the valuation of residential properties according to the level of energy intensity seems obvious in the face of rising energy costs for heating purposes; however, the literature on real estate valuation methods has not yet provided an answer to the question of how the energy intensity of a building affects the market value of residential units it consists of.

In the latest edition of European property valuation standards (European property valuation standards..., 2016) TEGOVA pays particular attention to the role of the real estate appraiser in the valuation process of buildings with Energy Performance Certificates (EPC), suggesting that they should also refer to the EPC (WESW8 Standard) in the set of documents to be included in the valuation. Therefore, the energy intensity of buildings becomes an additional parameter taken into account in the process of estimating the value of real estate, which additionally justifies the topic of this study. In the paper, the energy intensity of a residential property, understood here as the demand of multi-family residential buildings for energy for heating purposes, will be the basis for the assessment of the impact of proposed variants of features (including the thermoenergy performance of units evaluated by their location in the building) on the market value of residential units.

\section{Literature review}

\subsection{Energy consumption of buildings in the context of binding legal regulations}

Since Poland's accession to the European Union on 1 May 2004 Polish legislation is being amended, as a part of the Member States' obligations and with the respect to the idea of using energy at a reasonably low level, in order to achieve measurable levels of energy savings and environmental benefits by 2020, including a $20 \%$ increase in efficient energy use, a $20 \%$ increase of energy consumption from renewable sources, a $20 \%$ reduction in carbon dioxide emissions (Directive of the European Parliament and of the Council on the promotion of the use of energy from renewable sources), and the Council on efficiency ...). However, according to analysts (Kułaga, 2017), , the decrease in energy consumption was about $9.5 \%$ in the period 2000-2014.

In reference to energy consumption by residential buildings, energy efficiency can be defined as the best utility effect (the lowest possible energy loss to the environment and the highest possible comfort of use) with the lowest possible energy consumption (www.miir.gov.pl...). At the same time, energy efficiency is directly dependent on the energy consumption of the building itself, i.e. on the amount of energy necessary to deliver in order for the building to be used in accordance with its intended function. In the case of residential buildings, it is necessary to supply energy for heating and living purposes (including hot water, energy for preparing meals). The EU requirements concerning the energy consumption of buildings and its impact on the residential real estate market, based on the EU directives, including Directive 2010/31/EU of the European Parliament and of the Council of 19 May 2010 on the energy performance of buildings (recast), have been implemented into Polish conditions in technical and building laws (Construction Law...) and in regulations concerning real estate management (Real Estate Management Law...) .

In particular, the energy demand of buildings is the object of an analysis performed as a part of the energy performance certificate (Regulation on setting the characteristics...), which is to be used to obtain reliable information on the building by all participants in the property market, including property valuers. 
The result of issuing energy performance certificates are annual indicators of a building's or its part's demand for: primary energy from non-renewable sources, final energy (which includes the efficiency of technical building systems) and use energy (which reflects the thermal quality of the building envelope).

Data included in the energy performance certificate together with recommendations on how to improve the energy performance (which is economically viable and technically feasible) - are required for use by the property valuer (Article 155 (1) of the Act on real estate management ...).

In the situation of a poor market of energy performance certificates, which is still present in Poland, these documents are not used to compare the valued property - for which the certificate has been issued - with similar properties with no certificates, or with certificates containing irrelevant information. After many years of use, a significant share of expenditure on the maintenance of a property more and more often induces future users to seek a balance between the investment costs (market price) per unit and the costs of its operation. Therefore, sun exposure as well as a residential unit's position in the building (far end, central) should be added to the features that determine its energy efficiency.

\subsection{Impact of energy efficiency on the market value of real estate in terms of existing scientific achievements}

For about twenty years, both housing cooperatives and housing communities have been carrying out investments in the thermal upgrading of older buildings, aiming to reduce the operating costs of the managed housing stock by reducing its energy intensity. The energy intensity can be identified with the energy efficiency of a building, measured by the ability to satisfy the needs related to the function of the building with the lowest (optimum) level of supplied energy and the thermal comfort of the users. This comfort is ensured by the quality of the ventilation air and the internal temperature. In residential units, the optimum comfort is achieved when temperature in bathrooms and toilets is $24^{\circ} \mathrm{C}$ and $20^{\circ} \mathrm{C}$ in other rooms (kitchen, hallway, rooms). Financial outlays on investments related to thermal upgrading are high, and it takes years to wait for measurable effects in the form of savings. Nevertheless, these are works that result in a reduction of heat energy consumption, in higher thermal comfort for users, improved ventilated air quality, better aesthetics as well as in higher competitiveness on the market of dwellings located in prefabricated concrete slab buildings constructed in the 1970s (Foryś, 2012).

The subject of the market value of real estate seen from the perspective of energy consumption is still rarely discussed in scientific studies. There are no substantive guidelines and good practice rules. The existing literature on the subject provides theoretical considerations on energy-saving buildings (Dydenko, 2014) or energy consumption by insulated residential buildings (Korona, 2000). The authors analyze the profitability of investments in thermal upgrading made by housing cooperatives with the view to reducing operating costs related to the consumption of energy for central heating, hot water (reduction of energy consumption and contracted capacity) and electricity (Sujkowski, 2014). In the literature, attempts have also been made to analyze the effect of the thermal upgrading of buildings on the increase in the market value of residential units in cooperative housing stock (Foryś \& Nowak, 2012). Examples of studies in this respect (Foryś, 2006), carried out on the housing stock of one of housing estates located on the outskirts of the Szczecin, showed that, in 2001-2002, (the first years of thermal upgrading processes), an increase in prices for cooperative rights to premises was recorded in insulated buildings at the level of $15-18 \%$ in comparison to buildings before insulation, while in the case of buildings that had been included in renovation plans, prices of properties a year before the investment were $6 \%$ higher.

In order to answer the question of whether potential buyers were willing to pay more for a residential unit in a building with better energy performance, an analysis was also conducted of multifamily housing stock in Olsztyn (BEŁEJ \& GULMONTOWICZ, 2009). The study covered blocks of flats built from prefabricated slabs traded between 2004 and 2007. The analysis of weights of market features was carried out using two methods of statistical market analysis: the matrix of correlation of variables and multiple regression. It was found that thermal upgrading has the lowest impact among the attributes adopted in the study and is not significantly related to the price of residential units (useful floor space area, location, position on the floor, thermal upgrading). In another study (PUTEKSZELĄG \& ZIEMBICKA, 2016), an analysis of the impact of energy efficiency being the effect of thermal upgrading on the market price of flats on the Szczecin real estate market in 2007-2015 was carried out 
on the example of a prefabricated slab development in the city center. The authors concluded that, in the case of buildings located in the center of Szczecin, there were no significant differences between prices before and after thermal upgrading. As a result of thermal upgrading, prices did not increase, but the positive effect was that potential buyers started identifying thermal upgrading with the better technical condition of the building by the upgrading of the façade quality. Therefore, the accompanying outcome of the thermal upgrading is the improved aesthetics of the façade, which may also contribute to reducing the loss of value of the property as a result of slower technical (ZIEMBICKA, 2016) and economic wear and tear. However, the benefits of thermal upgrading, apart from the aesthetical aspect, are often difficult to determine, because the prices of residential units with different energy performance may be similar. The reasons can also be found in the immature market of energy performance certificates.

In principle, the Energy Performance Certificate was designed to provide information to market participants about the annual operating costs related to utilities and to be a distinguishing mark of the quality of a property. However, the energy certificate, containing a collection of incomprehensible indices describing the annual energy demand for various purposes, is not seen by the real estate market as a price forming attribute and is most often ignored in transaction price negotiations. The problem also arises when valuing the rights to real estate, because due to the poor market of certificates, the valuer is not able to compare a property with similar energy-performance characteristics with other properties, for which no certificate of characteristics has been prepared or the certificate is no longer valid. The issues discussed here call for the observation of the market and for the search for new tools to assess energy efficiency of residential units in multi-family buildings. Since most of the old housing stock has already been insulated, the feature called "thermal upgrading" seems to be relevant only from the point of view of maintaining aesthetics and undisturbed technical condition in subsequent years of use. Buildings and residential units should, therefore, be assessed against other criteria that may have an impact on energy efficiency, such as the location of the building and dwellings relative to sun exposure, the position of dwellings inside the building or the lay-out of rooms in the flat. It should be noted that the cost-intensive demand for district heating is conditioned by the acquisition of free heat from the environment as a result of sun exposure. The position considered the best in the building is in the middle (not peripheral, i.e. at the end of a wall). This is evidenced by the results of energy consumption for heating purposes by flats in buildings in Zielona Góra (ALSABRA, PIGALSKI \& MACIEJEWSKI, 2010). The authors carried out an analysis to assess the potential costs of one-, two- and three-room flats located in low buildings on floors from I to IV, described as peripheral and middle. The highest energy consumption $(0.4 \mathrm{GJ} / \mathrm{m} 2)$ was observed in 2room units located on ground floors (above the basements) and on the top floor $(0.37 \mathrm{GJ} / \mathrm{m} 2)$. Many buyers equate the location of the building in relation to the directions of the world and the location of the property in relation to end walls of the building with energy efficiency. This leads researchers to seek an answer to the question of whether the above attributes affect the value of residential properties.

\section{Purpose and test methods}

\subsection{Purpose and scope of the study}

The paper will attempt to determine the impact of the energy intensity of buildings on the market value of residential units in a selected housing estate in Szczecin, in a situation where the certificates of energy performance of the valued unit as well as the units accepted for comparison are not available to the property valuer. For this purpose, the authors have distinguished two groups of features and their attributes influencing the value of a property. In Table 1, the sizes of units from the analyzed database are grouped in relation to the normative useful floor space in force in the years 1959 and 1974 in the given categories, in the blocks of flats made of prefabricated concrete slabs.

The analysis is based on data from the "Dąb" Housing Cooperative, a collection of public statistics and information, databases and the authors' own research. The scope of the study covers some of the buildings from the stock of the Housing Cooperative - built in prefabricated slab technology (mainly the Szczecin system), between 1979 and 1984. Data concerning readings for energy consumption and transaction data from the secondary market of residential units in the above mentioned buildings in 2004 were analyzed. 
Table 1

Structure of the housing stock and the distribution of the useful floor space of dwellings traded on secondary market depending on the normative floor space on the example of selected buildings in the Słoneczne housing estate in Szczecin

\begin{tabular}{ccccc}
\hline $\begin{array}{c}\text { Dwelling } \\
\text { category by } \\
\text { number of } \\
\text { residents }\end{array}$ & \multicolumn{2}{c}{$\begin{array}{c}\text { Normative floor space } \\
\left(\mathrm{m}^{2}\right)\end{array}$} & \multicolumn{2}{c}{$\begin{array}{c}\text { Useful floor space } \\
\text { in stock under study }\end{array}$} \\
\cline { 2 - 5 } & 1959 & 1974 & High buildings & Low buildings \\
\hline M-1 & $17-20$ & $25-28$ & - & - \\
\hline M-2 & $24-30$ & $30-35(36)$ & $27.10-31.0$ & 33.10 \\
\hline M-3 & $33-38$ & $44-48(52)$ & $48.50-49.0$ & 44.40 \\
\hline M-4 & $42-48$ & $56-61(62)$ & $56.2-59.70$ & $53.40-57.90$ \\
\hline M-5 & $51-57$ & $65-70(73)$ & $69.80-77.10$ & $63.60-74.80$ \\
\hline M-6 & $59-65$ & $75-85$ & - & $84.30-86.30$ \\
\cline { 2 - 3 } \cline { 4 - 5 } & $67-71$ & 75 & & \\
\hline
\end{tabular}

Source: own study based on (Foryś, 2013, pp. 114; Korzeniewski, 1980, pp. 61, 65).

The area under study included the following streets: Jasna, Kostki Napierskiego, Rydla, Łubinowa and Lniana. Public transport stops are located on the above listed streets, with the exception of Rydla and Kostki Napierskiego.. For the purpose of the analysis, it was assumed that access to public transport is close when the buildings are located on streets which public transport runs along, and distant when the buildings were located inside the housing estate - on Rydla and Kostki Napierskiego streets, which made it necessary to walk a longer distance to a public transport stop.

The development in the studied area is compact with residential buildings with basements, both high (12 above-ground floors) and low (5 above-ground floors). The study found that the favorable ranking of the neighbourhood and surroundings of residential buildings was conditioned by the close distance to schools and shops. The characteristics of units with better market quotes included a position on an intermediate floor (all floors except the top and ground floors) and a small useful floor space, which, for a unit of the two-room category M-2 (a room with a separate kitchen and a bathroom with a toilet), did not exceed $33.1 \mathrm{~m}^{2}$. Three-room units of the M-3 type (two rooms with a kitchen and a bathroom and a separate toilet, which were typical of units with more than two rooms) up to $49.0 \mathrm{~m}^{2}$ and four-room units of M-4 type, with an area up to $59.7 \mathrm{~m}^{2}$. The least attractive were large units of the M-5 type, with a useful floor space of $63.6 \mathrm{~m}^{2}$ to $77.1 \mathrm{~m}^{2}$ and M-6, with six separate rooms (5 rooms and a kitchen) and a surface area from $84.3 \mathrm{~m}^{2}$ to $86.3 \mathrm{~m}^{2}$.

In the analysed comparative database, units that were insulated and in the process of insulation were more attractive than units that were not insulated. Buyers considered thermal upgrading to be equivalent with good technical condition, while bad technical condition was typically attributed to non-insulated buildings. Additional attributes of units which were incorporated in the extended variant of the characteristics that included the evaluation of units in terms of their energy efficiency were the consumption of heat energy, the position of the unit in the building (better for units located in the middle of the building, not adjoining an end wall; and worse when positioned adjacent to an end wall) and the unit's sun exposure. As a result of local real estate market research, the most attractive were units facing the east, south-east and north-west. The second most attractive ones were those facing the south, southwest or west, and the ones considered the least attractive by buyers had a living room facing the north and north-east. In the case of this particular characteristic, the living room played an important role, as it is used the longest during the day. The study adopted the following coding of attribute variants:

1. Type of building: best -3 , average -2 , worse than average -1 , worst -0 ;

2. Neighborhood and surroundings: favorable -1 , unfavorable -0 ;

3. Access to the public transport system: close -1 ; remote - 0 ;

4. Floor position : middle - 1 ; peripheral - 0 ;

5. Size: small - 2; average -1; big - 0;

6. Technical condition of building: good -1 ; bad -0 ;

7. Sun exposure: best - 2; average - 1 ; worst - 0 ; 
8. Consumption of heat energy: lowest -3 , average -2 , big - 1 , very big - 0 ;

9. Position in the building: better - 1; worse - 0 .

Base (classic) features, i.e. building type, neighborhood and surroundings, access to public transport, floor position, useful floor space/number of rooms, technical condition of the building were supplemented by three additional features, i.e. sun exposure of the unit (living room), consumption of heating units, position of the unit in the building. The position of a unit in the body of a building determines the heat loss to the environment depending on the number of building partitions in contact with the outside air. Also, the local market research shows that the sun exposure of the unit (living room) has an effect on the users' thermal comfort during $t$ hours when the living room is most frequently used. Therefore, buyers were willing to pay the most for properties with the best sun exposure in living rooms facing east, south-east and north-west. Features and attributes determining the energy consumption of buildings and residential units (marked in Table 2 with numbers 7,8 , and 9) were added intuitively on the basis of the authors' professional experience (Table 2 ), and their verification with statistical and econometric methods makes it possible to determine which of them are price forming. In the extended variant, the proposed features allowing for a simple description are based on knowledge regarding the distribution of units in the body of the building and their sun exposure. However, aggregated data on energy consumption can only be obtained from property managers or housing cooperatives, which was a major impediment in this study.

Table 2

Attributes for two variants of features

\begin{tabular}{|c|c|c|c|c|c|c|}
\hline No & $\mathrm{Va}$ & ciant & Feature & $\begin{array}{l}\text { Feature } \\
\text { attribute }\end{array}$ & $\begin{array}{l}\text { Attribute } \\
\text { variant } \\
\text { coding }\end{array}$ & Description \\
\hline \multirow{4}{*}{1} & \multirow{15}{*}{ 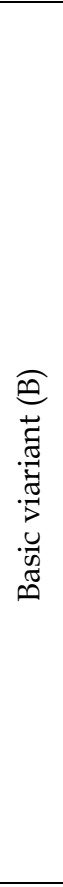 } & \multirow{15}{*}{ 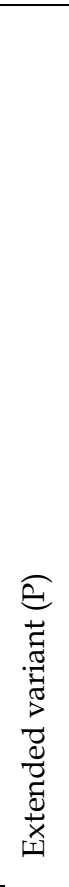 } & \multirow{4}{*}{ Building type } & B3 & 3 & high building- cascade \\
\hline & & & & B4 & 2 & all low buildings \\
\hline & & & & B1 & 1 & high building - a block \\
\hline & & & & B2 & 0 & high building - a star \\
\hline \multirow{2}{*}{2} & & & \multirow{2}{*}{$\begin{array}{l}\text { Neighborhood } \\
\text { and surroundings }\end{array}$} & beneficial & 1 & vicinity of schools and shops \\
\hline & & & & unbeneficial & 0 & remote from schools and shops \\
\hline \multirow[b]{2}{*}{3} & & & \multirow[b]{2}{*}{$\begin{array}{l}\text { Access to public } \\
\text { transport system }\end{array}$} & close & 0 & $\begin{array}{r}\text { peripheral areas between Jasna } \\
\text { and Łubinowa streets }\end{array}$ \\
\hline & & & & remote & 1 & $\begin{array}{r}\text { housing estate centre } \\
\text { Rydla and K. Napierskiego } \\
\text { streets } \\
\end{array}$ \\
\hline \multirow{2}{*}{4} & & & \multirow{2}{*}{ Floor position } & peripheral & 0 & ground floor, top floor \\
\hline & & & & middle & 1 & other middle floors \\
\hline \multirow{3}{*}{5} & & & \multirow{3}{*}{$\begin{array}{l}\text { Useful floor } \\
\text { space/ } \\
\text { number of rooms }\end{array}$} & small & 2 & $M-2 / 27.1 m^{2}-33.10 m^{2}$ \\
\hline & & & & average & 1 & $\begin{array}{l}\text { M-3/44.4m²-49.00m² } \\
M-4 / 53.4 m^{2}-59.70 m^{2}\end{array}$ \\
\hline & & & & big & 0 & $\begin{array}{l}\text { M-5/63.6m²-77.10m² } \\
\text { M-6/84.3m²-86.30m } \\
\end{array}$ \\
\hline \multirow[t]{2}{*}{6} & & & \multirow{2}{*}{$\begin{array}{l}\text { Technical } \\
\text { condition of } \\
\text { building }\end{array}$} & good & 1 & $\begin{array}{r}\text { Insulated or being insulated } \\
\text { building }\end{array}$ \\
\hline & & & & bad & 0 & non-insulated building \\
\hline \multirow{3}{*}{7} & & & \multirow{3}{*}{$\begin{array}{l}\text { Unit's (living } \\
\text { room's) sun } \\
\text { exposure }\end{array}$} & best & 2 & $\begin{array}{r}\text { east } \\
\text { south-east } \\
\text { north-west } \\
\end{array}$ \\
\hline & & & & average & 1 & $\begin{array}{r}\text { south } \\
\text { south-west } \\
\text { west } \\
\end{array}$ \\
\hline & & & & worst & 0 & north; north-east \\
\hline \multirow{4}{*}{8} & & & \multirow{4}{*}{$\begin{array}{l}\text { Heat energy } \\
\text { consumption }\end{array}$} & lowest & 0 & reading units $/ \mathrm{m}^{2}$ \\
\hline & & & & average & 1 & reading units $/ \mathrm{m}^{2}$ \\
\hline & & & & big & 2 & reading units $/ \mathrm{m}^{2}$ \\
\hline & & & & very big & 3 & reading units $/ \mathrm{m}^{2}$ \\
\hline 9 & & & Unit's position in & better & 0 & middle - unit inside building, \\
\hline
\end{tabular}




\begin{tabular}{llrr}
\hline building & & & not adjoining an end wall \\
\cline { 2 - 4 } & worse & 1 & peripheral - unit adjoining an \\
end wall
\end{tabular}

Source: own study.

In order to demonstrate the relationships, the authors estimated the market value of selected twoand three-room units (four units of each type), in one variant of the characteristics referred to as "extended features", including those considered to be classic (1-6) and the features added to them (7-9) that had been considered to be related to the energy intensity of units in buildings presented in Table 2. In this variant, the explanatory variables referred to as classic were extended by three additional attributes such as: the sun exposure of the unit (living room), consumption of heating units, and position of the unit inside the building which made it possible to assess the energy consumption of the unit and then set the direction of further research.

\subsection{Research methods}

In the absence of a clearly defined procedure for the statistical market analysis method in the comparative approach, researchers use classical and non-classical econometric models to determine the property value, most often including linear regression of many variables. Non-linear models fall into two groups, i.e.: models that can be reduced to linear models after appropriate transformation, and non-transformable non-linear models for which there are no methods of transformation to linear models (Coulson, Dong \& Sing, 2018). In each valuation model it is necessary to determine features describing the object under study. Hence, in the first stage of this study, the variables significantly affecting the value of a property were specified. This was done by determining the Spearman's rank correlation coefficients due to the scales which the features of the examined objects were measured on (Kendall, 1948, p. 29).

Then, for the obtained set of variables and randomly selected cooperative residential units, transactions were valued by means of:

1) linear regression,

2) a non-classical mass appraisal model, i.e. the Szczecin mass appraisal algorithm,

3) individual valuation (using the average price adjustment method).

Linear models, in the form of structural parameters, determine the power of direct interactions of an exogenous variable with an endogenous variable, and are commonly used because they can be easily interpreted (BAILEY, Muth \& Nurse, 1963). The relationships between measurable features can be presented by means of a mathematical model describing those relationships which are called regression analysis. A variation of regression is also stepwise forward regression, where procedures consist in adding variables that are most strongly correlated with the dependent variable in subsequent versions of the model (Grabiński, Wydymus \& Zeliaś, 1982). What is assessed is the significance of parameters and the significance of the determination coefficient (Putek- Szeląg, 2004).

With each step of the analysis (one variable - one step), predicators are introduced or removed. Threshold values (input threshold and exit threshold) are based on the F-Snedecor statistics of the significance analysis of a given predictive factor, in terms of the predictive value of a dependent variable.

In the case of non-linear models, their functional form and the set of independent variables adopted to describe the studied phenomenon should be justified by a good theory. Property valuers have been using more and more complex methods of analyzing transaction prices, which are derived from related sciences (Gnat, 2010). As a response to the non-linearity of phenomena occurring in the economy, the study used a non-classical (non-linear) mass appraisal model, the so-called Szczecin mass appraisal model, which enables the estimation of a large number of properties in a short time, using a uniform technology (Foryś \& Putek-Szeląg, 2018). For this model, the influence of particular features on the value according to the general Formula 1-3 (Hozer et. al., 1999) is presented in Formula 4-5 (Lis, 2005). In the Szczecin algorithm of mass appraisal of real estate presented below:

$$
\widehat{W}_{j i}=W W R_{j} \cdot \operatorname{pow}_{i} \cdot W_{b a z} \cdot \prod_{k=1}^{K}\left(1+A_{k}\right)
$$

where:

$\widehat{W}_{j i} \quad$ - market value of $\mathrm{i}$-th property in j-th elementary area,

$W W R_{j}$ - market value coefficient in j-th elementary area $(j=1,2, \ldots, J)$, 


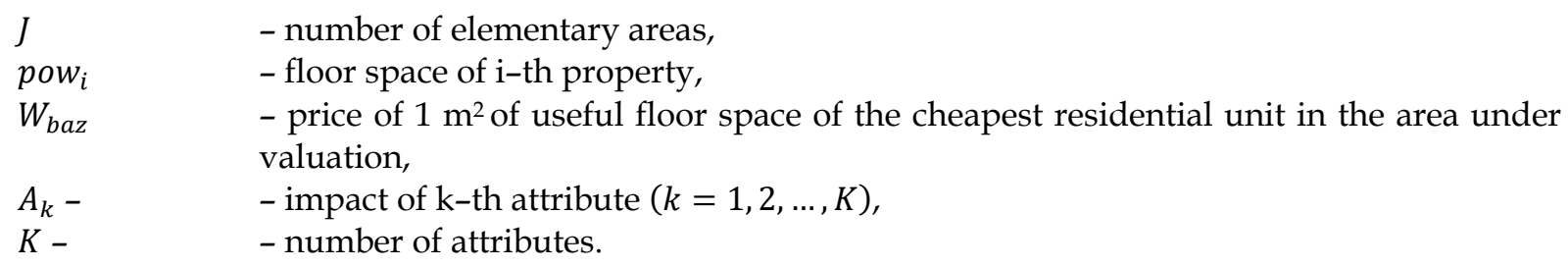

WWRj coefficients are calculated for each elementary area as the arithmetic mean of WWRi (Formula 2) calculated for individual properties - representatives of each elementary area. These are the quotient of the market price of the property (Formula 3) and the hypothetical value of the property determined on the basis of Formula 4.

$$
\begin{gathered}
W W R_{j}=\frac{\sum_{i=1}^{l} W W R_{i}}{l} \\
W W R_{i}=\frac{W R_{r i}}{\widehat{W}_{h i}} \\
\widehat{W}_{h i}=\operatorname{pow}_{i} \cdot W_{b a z} \cdot \prod_{k=1}^{K}\left(1+A_{k}\right)
\end{gathered}
$$

where:

$W W R_{i} \quad$ - ratio between market price and hypothetical value of the i-th residential unit,

1

$W R_{r i}$

$\widehat{W}_{h i}$

- number of residential units in j-th elementary area,

- market price of i-th residential unit calculated by a valuer,

- hypothetical value of residential unit calculated by means of the model.

Attributes are displayed on a qualitative scale, Spearman's coefficient (Rxy) was used to determine the influence of particular features on the property value.

Calibration of residential unit attributes was carried out on the basis of a mathematical formula, where the weightings (1+Ak) were determined following the extreme value theory (LIS 2003):

$$
1+A_{k}=\left(1-\frac{1}{2} \rho\right)+\left[\left(1+\frac{1}{2} \rho\right)-\left(1-\frac{1}{2} \rho\right)\right] \cdot \frac{l_{k p}}{k_{p}-1}=\left(1-\frac{1}{2} \rho\right)+\rho \frac{l_{k p}}{k_{p}-1}
$$

where:

$$
\begin{array}{ll}
1_{\mathrm{kp}} & -\mathrm{p} \text {-th category of k-th attribute, } \\
\rho & \text { - standardized Spearman's coefficients. }
\end{array}
$$

To be able to fully explain the property value, the values of relevant Spearman's coefficients were adjusted so that the sum of their absolute values is equal to 1 .

For comparison with the estimation methodology commonly used by property valuers, the method of correcting the average price was also used as one of the methods of calculating the property market value. In the comparative approach, at least a dozen or so similar residential units which have been traded on the market and with known prices, selected comparative features, and the terms of the transaction are used for comparison.

The market value is estimated by adjusting the average price of a similar property on the basis of weightings which take into account differences in the features of such a property.

Table 2 shows the characteristics of comparative properties and information collected from the secondary market of residential units with a cooperative ownership right, including the dates and terms of transactions in the year covered by the survey (2004). The adoption of the year 2004 for the survey was dictated by uniform rules of settling heat consumption by the housing cooperative by means of new measurement devices. For the year 2004, an evenly distributed structure was also observed, also as a result of the completed process of the thermal upgrading of the housing stock under study.

In the next step, the results of the estimation of the property value obtained in the course of individual valuation performed using the average price adjustment were compared with the results of property valuation by means of mass appraisal algorithm and step regression.

The results obtained were compared using a relative error, calculated on the basis of the following formula:

$$
\partial=\frac{\left|W_{j i}-W R_{r i}\right|}{W_{j i}} \cdot 100 \%
$$

Additionally, the following measures of variability were calculated: 
where:

$$
\begin{gathered}
S e=\sqrt{\frac{\left(W R_{r i}-W R_{j i}\right)^{2}}{n}} \\
V s=\frac{S e}{\overline{W R_{r l}}} \cdot 100 \%
\end{gathered}
$$

Se $\quad-$ standard deviation of the value of $1 \mathrm{~m}^{2}$ of useful floor space,

Vs - variability coefficient of the value of $1 \mathrm{~m}^{2}$ of useful floor space.

The lower the values of the variability measures, the closer the estimated values, which allows for interchangeability between the three methods under study.

\section{Empirical data and results}

\subsection{Characteristics of housing stock under study}

As the study is preliminary to a wider project, the following data were analyzed from the first year (2004) for which complete information was obtained and which was considered as the test year also due to the installation process of heat cost allocators. The results obtained and the proposed methods will be used for further in-depth research in subsequent years. In the year under study, a total of 67 transactions were recorded. There were the following numbers of transactions in individual quarters (Table 3):

Table 3

Structure of the price of $1 \mathrm{~m}^{2}$ of floor space of residential units in area under study

\begin{tabular}{lrrrrrrrr}
\hline Quarter & $\begin{array}{c}\text { Mean } \\
\left(\mathrm{PLN} / \mathrm{m}^{2}\right)\end{array}$ & $\mathrm{N}$ & $\begin{array}{c}\text { Standard } \\
\text { deviation } \\
\left(\mathrm{PLN} / \mathrm{m}^{2}\right)\end{array}$ & $\begin{array}{c}\text { Min } \\
\left(\mathrm{PLN} / \mathrm{m}^{2}\right)\end{array}$ & $\begin{array}{c}\text { Max } \\
\left(\mathrm{PLN} / \mathrm{m}^{2}\right)\end{array}$ & $\begin{array}{c}\mathrm{Q} 14 \\
\left(\mathrm{PLN} / \mathrm{m}^{2}\right)\end{array}$ & $\begin{array}{c}\mathrm{M} \\
\left(\mathrm{PLN} / \mathrm{m}^{2}\right)\end{array}$ & $\begin{array}{c}\mathrm{Q} 34 \\
\left(\mathrm{PLN} / \mathrm{m}^{2}\right)\end{array}$ \\
\hline $\mathrm{I}$ & 1780.65 & 13 & 273.97 & 1346.91 & 2362.46 & 1612.90 & 1768.02 & 1917.53 \\
\hline II & 1734.24 & 14 & 231.27 & 1312.34 & 2093.80 & 1597.87 & 1724.37 & 1933.96 \\
\hline III & 1735.25 & 15 & 286.81 & 1289.40 & 2322.58 & 1484.89 & 1753.25 & 1967.74 \\
\hline IV & 1828.23 & 25 & 226.97 & 1443.30 & 2290.32 & 1650.94 & 1871.07 & 1979.38 \\
\hline Total & 1778.54 & 67 & 249.28 & 1289.40 & 2362.46 & 1612.90 & 1784.51 & 1959.18 \\
\hline
\end{tabular}

Source: own study.

The largest number of transactions in cooperative property rights to premises was recorded in the fourth quarter and, in that period, over $37 \%$ of transactions were carried out. The number of flats sold in the area of the surveyed streets is shown in Figure 1 in the next chapter.

\subsection{Analysis of structure of objects in groups}

For the purpose of the study, the shape of the building was analyzed, which allowed the initial group of eight building shapes to be divided into four types, depending on their height and shape as well as technical parameters (Table 4).

Table 4

Number of transactions concluded in 2004 by the types of buildings in analysed area and by the technical condition of buildings

\begin{tabular}{lccccc}
\hline \multirow{2}{*}{ Type of building } & $\begin{array}{c}\text { Total } \\
\text { number of } \\
\text { transactions }\end{array}$ & \% total & & \multicolumn{2}{c}{ Number of transactions in buildings: } \\
\cline { 5 - 7 } & 10 & 15 & 2 & 8 & $\begin{array}{c}\text { being } \\
\text { insulated }\end{array}$ \\
\hline B1 (single high-rise) & 18 & 27 & 8 & 6 & - \\
\hline B2 (star-type high-rise) & 21 & 31 & 2 & 19 & - \\
\hline $\begin{array}{l}\text { B3 (cascade-type high- } \\
\text { rise) }\end{array}$ & 18 & 27 & 6 & 12 & - \\
\hline B4 (all low buildings) & 67 & 100 & 18 & 45 & 4 \\
\hline \multicolumn{1}{c}{ Total } & & & &
\end{tabular}

Source: own study. 
The majority of residential units sold were 3-room units (27), followed by 2-room units (20), 4-room units (11) and bedsits (8). Also, one 5-room unit was sold. The highest unit price of PLN 2,362.4/ $\mathrm{m}^{2}$ was recorded in March 2004. The structure of the units sold on the streets under survey is shown in Figure 1.

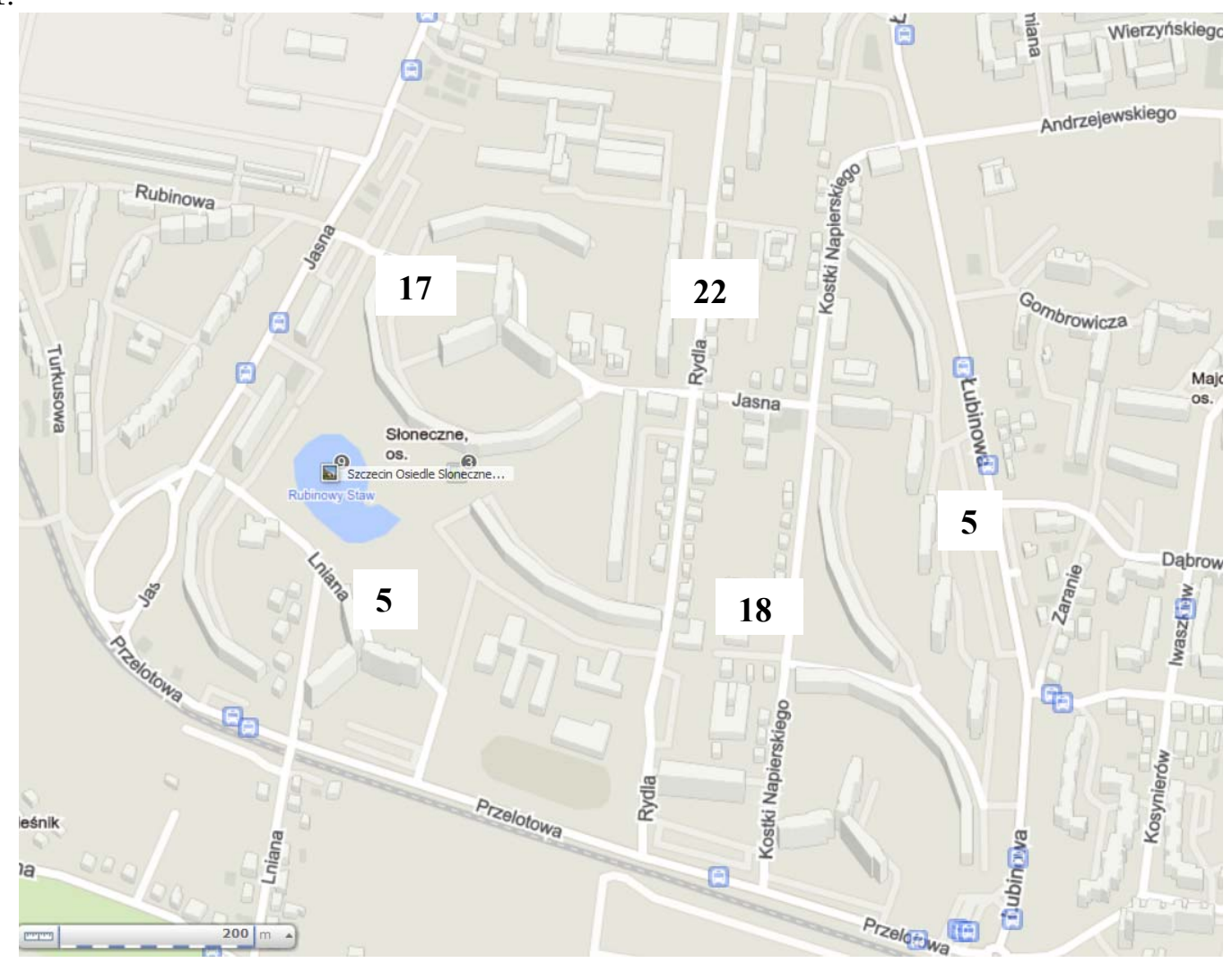

Fig. 1. Number of units sold located on the specified streets in the area under study. Source: own study based on https:/ / mapa.targeo.pl/14.6595418,53.377972,20.

In the analyzed housing stock, the majority of the buildings were high-rise buildings of the cascade type, whereas the fewest were buildings shaped as simple blocks. The highest average unit price (1928.45 PLN/m²) was recorded in the group of high cascade buildings marked as B3, and the lowest average price (1604.56 PLN/ m²) in high star-shaped buildings marked as B2. In B2 buildings, the most frequent observation (dominant) was the unit price of PLN $1577.32 / \mathrm{m}^{2}$, for $25 \%$ the unit price was no higher than PLN $1430.98 / \mathrm{m}^{2}$ (regarded as an irrelevant dominant), while $75 \%$ of units reached a unit price of no lower than PLN 1795.92/ $\mathrm{m}^{2}$. The recorded maximum price was PLN 1967.74/ $\mathrm{m}^{2}$ (regarded as an irrelevant dominant). In the group of buildings marked as B3 - the dominant was PLN $1917.53 / \mathrm{m}^{2}$. In $25 \%$ of observations, the unit price did not exceed PLN $1731.96 / \mathrm{m}^{2}$, while $75 \%$ of units reached a unit price of over PLN 2129.03/ $\mathrm{m}^{2}$. The recorded maximum price was PLN $2362.846 / \mathrm{m}^{2}$ (Table 5).

Table 5

Structure of price of $1 \mathrm{~m}^{2}$ of floor space by attributes of residential units in area under study in 2004

\begin{tabular}{|c|c|c|c|c|c|c|c|c|}
\hline 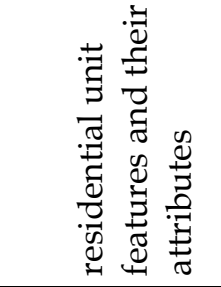 & 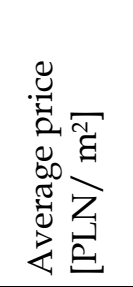 & 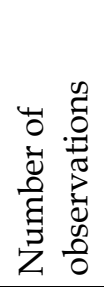 & 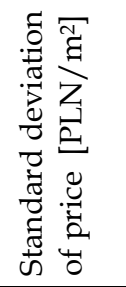 & 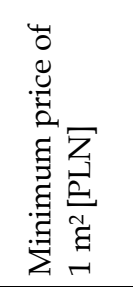 & 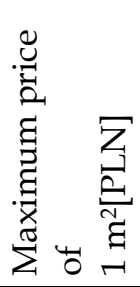 & 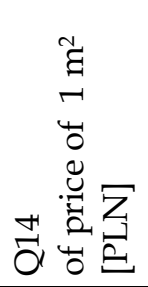 & 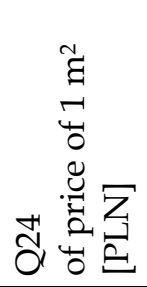 & 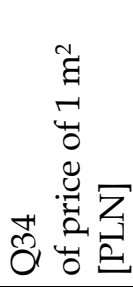 \\
\hline \multicolumn{9}{|l|}{ Building type* } \\
\hline 1 & 24.35 & 10 & & & 093.80 & & & 1959.18 \\
\hline 2 & 1604.56 & 18 & 221.40 & 1289.40 & 1967.74 & 1430.98 & 1577.32 & 1795.92 \\
\hline
\end{tabular}




\section{S sciendo}

\begin{tabular}{|c|c|c|c|c|c|c|c|c|}
\hline B3 & 1928.45 & 21 & 243.85 & 1540.40 & 2362.46 & 1731.96 & 1917.53 & 2129.03 \\
\hline B4 & 1807.73 & 18 & 162.82 & 1522.25 & 2018.87 & 1650.94 & 1839.62 & 1933.96 \\
\hline \multicolumn{9}{|c|}{ Neighbourhood and surroundings } \\
\hline favourable & 1888.07 & 13 & 247.44 & 1540.40 & 2322.58 & 1711.34 & 1797.15 & 1986.53 \\
\hline unfavourable & 1752.17 & 54 & 244.69 & 1289.40 & 2362.46 & 1590.91 & 1760.63 & 1933.96 \\
\hline \multicolumn{9}{|c|}{ Access to public transport } \\
\hline remote & 1908.98 & 22 & 254.90 & 1500.00 & 2362.46 & 1711.34 & 1917.53 & 2129.03 \\
\hline close & 1714.77 & 45 & 222.57 & 1289.40 & 2093.80 & 1572.33 & 1731.96 & 1897.96 \\
\hline \multicolumn{9}{|c|}{ Unit position on floor } \\
\hline peripheral & 1727.70 & 11 & 183.95 & 1443.30 & 1986.53 & 1597.87 & 1697.89 & 1967.74 \\
\hline middle & 1788.53 & 56 & 260.38 & 1289.40 & 2362.46 & 1614.53 & 1796.54 & 1958.24 \\
\hline \multicolumn{9}{|c|}{ Useful floor space/number of rooms } \\
\hline big & 1636.81 & 23 & 231.99 & 1289.40 & 1988.99 & 1445.47 & 1650.94 & 1871.07 \\
\hline average & 1794.13 & 36 & 179.36 & 1430.98 & 2135.23 & 1662.26 & 1794.87 & 1945.63 \\
\hline small & 2115.87 & 8 & 242.10 & 1612.90 & 2362.46 & 2032.26 & 2137.10 & 2306.45 \\
\hline \multicolumn{9}{|c|}{ Technical condition of building } \\
\hline bad & 1712.13 & 6 & 232.85 & 1312.34 & 1933.96 & 1597.87 & 1766.47 & 1895.65 \\
\hline good & 1785.07 & 61 & 251.70 & 1289.40 & 2362.46 & 1616.16 & 1784.51 & 1967.74 \\
\hline \multicolumn{9}{|c|}{ Sun exposure of residential unit (living room) } \\
\hline best & 2041.14 & 9 & 318.66 & 1443.30 & 2362.46 & 1967.74 & 2129.03 & 2290.32 \\
\hline average & 1746.25 & 51 & 217.09 & 1289.40 & 2135.23 & 1590.91 & 1768.02 & 1933.96 \\
\hline worst & 1676.15 & 7 & 175.79 & 1303.78 & 1835.05 & 1649.49 & 1731.96 & 1784.51 \\
\hline \multicolumn{9}{|c|}{ Consumption of heat in units } \\
\hline very high & 1799.63 & 18 & 294.43 & 1346.91 & 2362.46 & 1612.90 & 1773.98 & 1959.18 \\
\hline high & 1780.07 & 15 & 278.74 & 1289.40 & 2322.58 & 1540.40 & 1795.92 & 1988.99 \\
\hline average & 1778.83 & 17 & 194.26 & 1430.98 & 2145.16 & 1649.49 & 1731.96 & 1897.06 \\
\hline lowest & 1754.56 & 17 & 239.57 & 1303.78 & 2018.87 & 1597.87 & 1808.18 & 1967.74 \\
\hline \multicolumn{9}{|c|}{ Residential unit's position in building } \\
\hline worse & 1578.07 & 11 & 251.31 & 1289.40 & 1986.53 & 1312.34 & 1500.00 & 1784.51 \\
\hline better & 1817.92 & 56 & 231.24 & 1346.91 & 2362.46 & 1639.18 & 1802.67 & 1973.56 \\
\hline
\end{tabular}

Source: own study.

In the year of study, the neighborhood and the surroundings were associated with the highest average price (PLN 1888.07/ $\mathrm{m}^{2}$ ) and the dominant at PLN $1797.15 / \mathrm{m}^{2}$ for a more favorable attribute (i.e. location in the vicinity of schools and shops), while the worse attribute was characterized by the average price of PLN $1752.17 / \mathrm{m}^{2}$, with the dominant at PLN $1,760.63 / \mathrm{m}^{2}$. The highest price for the better variant was PLN 2322.58 per $\mathrm{m}^{2}$ and the minimum price for the worse variant was PLN $1,289.40 / \mathrm{m}^{2}$. In 2004, the access to a public transport feature was valued in such a way that the better evaluation of the attribute, i.e. remote access to public transport, was at an average price of 1908.98 $\mathrm{PLN} / \mathrm{m}^{2}$, while the worse feature had a unit price of $1714.77 \mathrm{PLN} / \mathrm{m}^{2}$. The floor position of the unit showed a slight difference between of the better (middle position) and the worse feature (peripheral position, i.e. on the top or ground floor). The difference in the average price in 2004 was only 60.83 $\mathrm{PLN} / \mathrm{m}^{2}$. In the case of the better position, the maximum price was PLN $2363.46 / \mathrm{m}^{2}$ and the minimum price was PLN $1,289.40 / \mathrm{m}^{2}$. As for the useful floor space, the difference between the best (PLN $2115.87 / \mathrm{m}^{2}$ ) and the worst (PLN $1636.81 / \mathrm{m}^{2}$ ) price stood at PLN $479.06 / \mathrm{m}^{2}$. In the case of average-sized units, the dominant variant of the feature was PLN $1794.87 / \mathrm{m}^{2}$, the first quartile being PLN 1662.26 per $\mathrm{m} 2$ and the third quartile - PLN 1945.63/ $\mathrm{m}^{2}$. The technical condition of the building was defined as bad in the case of non-insulated buildings, and good for insulated buildings or those undergoing thermal upgrading in the year of study. Thermal upgrading of all the analysed buildings was completed in 2006. The diversification of attributes of the technical condition feature (between a good and bad attribute) was comparable to the floor position of a unit, and stood at $72.94 \mathrm{PLN} / \mathrm{m}^{2}$ for the average price in 2004, with the maximum price (for the better feature) being $2362.46 \mathrm{PLN} / \mathrm{m}^{2}$, and the lowest price (for the worse feature) amounting to $1312.34 \mathrm{PLN} / \mathrm{m}^{2}$. In 2004, the sun exposure feature which was regarded the best by buyers (east, south-east and north west) was reflected by an average price of PLN 2041.14/ $\mathrm{m}^{2}$, which was higher than the average variant (south, south-west and 
west exposure) by PLN $294.89 / \mathrm{m}^{2}$ (PLN $1746.25 / \mathrm{m}^{2}$ ), and than the worst variant (north-east exposure) by PLN 366.99 per $\mathrm{m} 2$ (PLN $1676.15 / \mathrm{m}^{2}$ ). In the case of the best variant of this feature, the dominant was PLN $2129.03 / \mathrm{m}^{2}$. In $25 \%$ of the observations, the unit price was no higher than PLN $1967.74 / \mathrm{m}^{2}$, while in $75 \%$ of cases, the unit price was no lower than PLN $2290.32 / \mathrm{m}^{2}$, with a maximum price of PLN $2362.46 / \mathrm{m}^{2}$. The consumption of heat units in 2004 showed a slight difference between the assigned attributes: the difference between the worst variant (for the highest consumption) and the best variant (for the lowest consumption of heat units) in the case of an average price amounted to PLN $25.51 / \mathrm{m}^{2}$. The maximum price for the lowest heat consumption was PLN $2362.46 / \mathrm{m}^{2}$ and the minimum price for the worst variant was PLN $1289.40 / \mathrm{m}^{2}$. The highest dominant was $1808.18 \mathrm{PLN} / \mathrm{m} 2$, while the lowest - PLN $1731.96 / \mathrm{m}^{2}$ (similar values). The position of the residential unit in the building showed a substantial difference between the two adopted attributes. The worse location (unit on an end wall) was reflected in an average price of PLN $1578.07 / \mathrm{m}^{2}$, while the price for the better location (middle unit) was higher by PLN $239.85 / \mathrm{m}^{2}$. The dominant factor for the better variant was PLN $1802.67 / \mathrm{m}^{2}$, and for the worse variant - PLN 1,500/ $\mathrm{m}^{2}$.

Among all the analyzed characteristics and their attributes, the unit price did not exceed PLN $2032.26 / \mathrm{m} 2$ in $25 \%$ of observations (small usable floor space of units), while the price of $75 \%$ of units was at least PLN 1784.51/m2 (for the worst sun exposure and worse position of the unit in the building).

\subsection{Scenarios for valuation of the market value of residential units in three variants}

In the first stage of the study, the authors specified those variables that significantly affected the value of real estate. From the set of candidates, the features that had the strongest effect on the property value were selected using Spearman's coefficient. The following features have a significant impact on the property price: the type of building, public transport accessibility, floor space, and position of the unit in the building, which is related to the energy performance of the unit, i.e. its sun exposure (Table $6)$.

Table 6

Correlation between the price of $1 \mathrm{~m}^{2}$ of a residential unit and its individual attributes

\begin{tabular}{|c|c|c|c|c|c|c|c|c|c|}
\hline 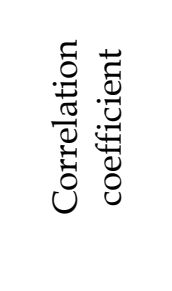 & 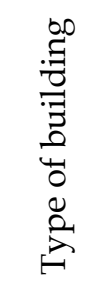 & 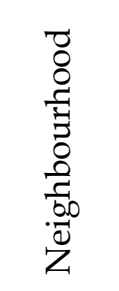 & 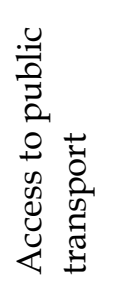 & 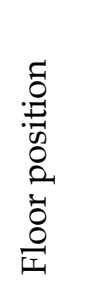 & 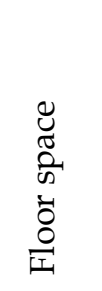 & 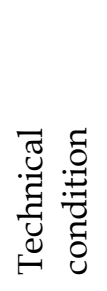 & 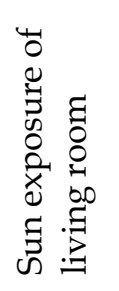 & 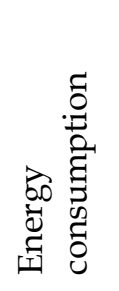 & 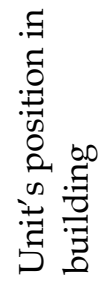 \\
\hline $\begin{array}{l}\text { Spearman } \\
\text { coefficient }\end{array}$ & 0.288 & -0.199 & -0.342 & 0.077 & 0.532 & 0.099 & -0.188 & -0.017 & 0.345 \\
\hline $\begin{array}{l}\text { Adjusted } \\
\text { Spearman } \\
\text { coefficient }\end{array}$ & 0.191 & & -0.227 & & 0.353 & & & & 0.229 \\
\hline
\end{tabular}

Source: own study.

These variables were then used to price eight units (one 2- and one 3-bedroom unit in each building type) selected in a stratified draw (ACZEL, 2000, S. 918-921). The lines in which the adjusted Spearman's coefficients are presented were calculated by adjusting the relevant absolute values of the coefficients of individual attributes so that their sum was equal to 1 (Table 7).

Table 7

Impact of individual attributes on the price of $1 \mathrm{~m}^{2}$ of a residential unit

\begin{tabular}{ccccc}
\hline `Attribute & Coding & $\begin{array}{c}\text { Spearman } \\
\text { coefficient }\end{array}$ & 1+Aij & Aij \% \\
\hline Building type & 0 & 0.191 & 0.9043 & -9.57 \\
\hline
\end{tabular}




\begin{tabular}{|c|c|c|c|c|}
\hline & 1 & & 0.9681 & -3.19 \\
\hline & 2 & & 1.0319 & 3.19 \\
\hline & 3 & & 1.0957 & 9.57 \\
\hline \multirow{2}{*}{$\begin{array}{l}\text { Access to } \\
\text { public } \\
\text { transport }\end{array}$} & 0 & \multirow{2}{*}{-0.227} & 1.1134 & 11.34 \\
\hline & 1 & & 0.8866 & -11.34 \\
\hline \multirow{3}{*}{ Floor space } & 0 & \multirow{3}{*}{0.353} & 0.8235 & -17.65 \\
\hline & 1 & & 1.0000 & 0 \\
\hline & 2 & & 1.1765 & 17.65 \\
\hline \multirow{3}{*}{$\begin{array}{l}\text { Unit's } \\
\text { position in } \\
\text { building }\end{array}$} & 0 & \multirow{3}{*}{0.229} & 0.8856 & -11.44 \\
\hline & 1 & & 1.0000 & 0 \\
\hline & 2 & & 1.1144 & 11.44 \\
\hline
\end{tabular}

Source: own study.

It was found that the strongest influence on the price was exerted by the unit floor space followed by public transport accessibility. The next two features were associated with energy performance, i.e. the unit's position in the building and the type of building. The results of the valuation have been presented in Table 9. Weights obtained with this method as well as attributes and their coding (Table 7) constituted the basis for valuation performed by means of the comparative approach and using the average price adjustment method, with minimum, maximum and average prices separately for each subgroup of similar properties selected for estimation: building B4 (Cmin= PLN1522 zl, Cmax=PLN2019, Cśr=PLN1810), building B3 (Cmin=PLN1540, Cmax=PLN2362, Cśr=PLN1954), building B2 (Cmin=PLN1289, Cmax=PLN1968, Cśr=PLN1600), building B1 (Cmin=PLN1312, Cmax=PLN2094, Cśr=PLN1727).

In the next step, residential units were valued on the basis of step-by-step regression. In this method the attributes found to be the most relevant were: the type of building and the floor space measured in $\mathrm{m} 2$. Price changes are explained in $47.85 \%$ of cases by the type of building and the floor space of the unit, which indicates a relatively low model fit. Actual prices differed from the values obtained on the basis of the model on average by +/- 191 PLN. The estimated values of parameters of the model variables are presented in Table 8 and the results of the valuation can be found in Table 9 .

Table 8

Parameters of residential unit price regression function

\begin{tabular}{lccc}
\hline Variable & Parameter value & Standard error & p-value \\
\hline $\mathrm{R}^{2}$ & 0.4763 & 185.24 & \\
& & & \\
Absolute term & 1356.12 & 96.92 & 0.000000 \\
Floor space & 251.84 & 37.97 & 0.000000 \\
Building type & 82.96 & 24.05 & 0.001054 \\
Unit's position in building & -168.90 & 68.82 & 0.017139 \\
Sun exposure of living room & 157.32 & 74.24 & 0.0383948 \\
\end{tabular}

\section{Source: own study.}

The obtained results indicate the highest divergence of transaction prices in the case of the nonclassical model, and the lowest in the case of the individual method (Table 9) and (Fig. 2).

The three estimation methods allow for the comparison of results obtained using standard deviation, the coefficient of variation and the relative forecast error (Table 10). 
Table 9

Scenarios for valuating the market value of residential units in the classic and non-classic variant

\begin{tabular}{|c|c|c|c|c|c|c|}
\hline 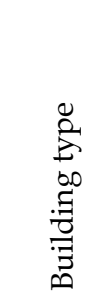 & 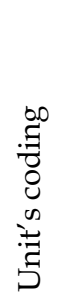 & 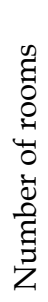 & 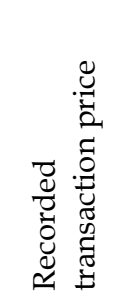 & 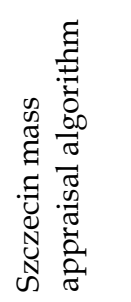 & 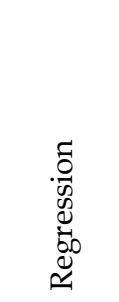 & 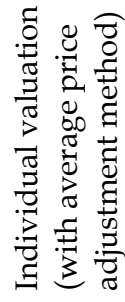 \\
\hline \multirow{2}{*}{$\left.\mathrm{B} 1^{*}\right)$} & L1 & 2 & 1814.43 & 1507.70 & 1652.68 & 1527.24 \\
\hline & L2 & 3 & 1616.16 & 1627.26 & 1523.20 & 1468.63 \\
\hline \multirow{2}{*}{ B2 } & L3 & 2 & 1731.96 & 1742.11 & 1736.05 & 1696.40 \\
\hline & L4 & 3 & 1675.04 & 1742.11 & 1603.02 & 1764.24 \\
\hline \multirow{2}{*}{ B3 } & L5 & 2 & 1793.81 & 2503.11 & 1819.43 & 1396.54 \\
\hline & L6 & 3 & 1797.15 & 2160.45 & 1727.97 & 1314.34 \\
\hline \multirow{2}{*}{ B4 } & L7 & 2 & 1768.02 & 1971.79 & 1951.51 & 1869.88 \\
\hline & L8 & 3 & 1808.18 & 1743.09 & 1723.45 & 1820.22 \\
\hline
\end{tabular}

Source: own study.

Table 10

Accuracy of estimating the market value of residential units in the classic variant and non-classic variant with real-life transaction prices

\begin{tabular}{|c|c|c|c|}
\hline Valuation model & $\begin{array}{l}\text { Standard deviation } \\
\qquad \mathrm{Se}^{\prime \prime}\left(\mathrm{zl} / \mathrm{m}^{2}\right)\end{array}$ & $\begin{array}{l}\text { Coefficient of } \\
\text { variability } \\
\text { „Vs" }(\%)\end{array}$ & 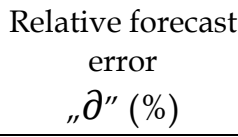 \\
\hline $\begin{array}{l}\text { non-classic } \\
\text { (mass appraisal algorithm) }\end{array}$ & 312.18 & 16.65 & 10.59 \\
\hline Multiple regression & 103.86 & 6.05 & 5.04 \\
\hline $\begin{array}{l}\text { Individual valuation } \\
\text { (average price adjustment) }\end{array}$ & 125.55 & 7.39 & 5.77 \\
\hline
\end{tabular}

Source: own study.

The results indicate a good fit between the obtained theoretical values and the actual transaction price in the case of multiple regression and individual valuation, and twice as bad in the case of the non-classic model. However, the assessments are mainly influenced by the divergence of ratings for units in building B3 (units L5 and L6) of the cascade high-rise, which is non-typical in relation to other buildings and presents the smallest variation in the value of the variable of heat unit consumption, because only two buildings out of 21 were not insulated. The smallest discrepancies between the model value and the real transaction price took place in the B2 building of the star high-rise type and in units L3 and L4, the group with a predominance of non-insulated buildings (Fig. 2).

\section{Summary and conclusions}

The obtained results confirm the view that valuers should take the energy intensity of a building, which can translate into higher operating costs in the future for the buyer, into account in the process of property valuation and estimating the market value of the premises. The estimated values, relative to the location of the residential units in the building in terms of energy intensity (e.g. sun exposure, 
directions of typical winds from Lake Dabie) gave convergent results in the case of two valuation models: multiple regression and valuation in the comparative approach. Outliers of the non-classical model may result from small samples of residential units used for comparison (a dozen or so transactions), selected from the transaction database concluded in a given year, assuming the building type as the criterion.

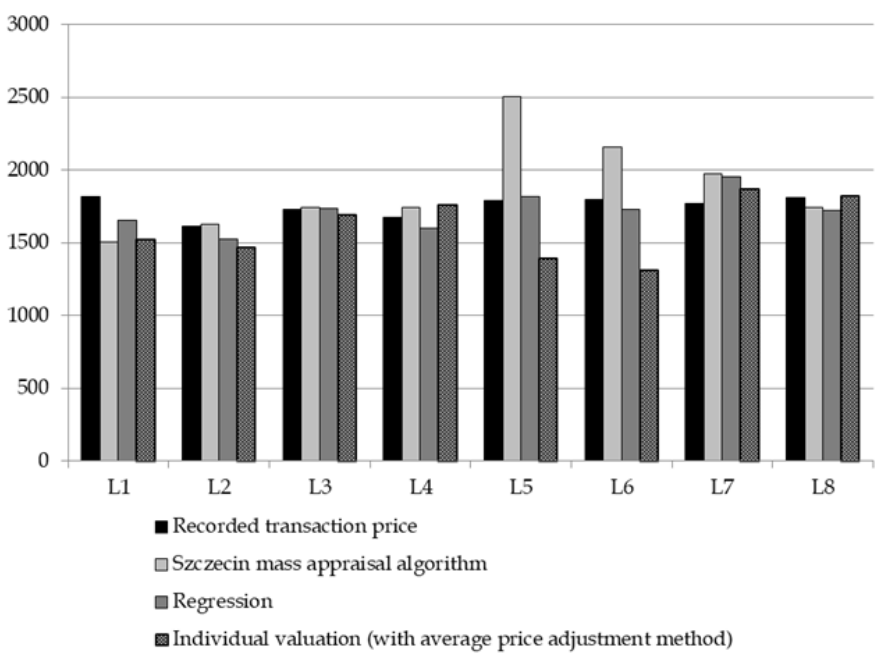

Fig. 2. Unit price of L1-L8 estimated using three methods vs. real transaction price. Source: own study.

In the next stages of the study, non-linear models will be tested and additional variables, including a time variable, will be taken into consideration. Attempts will also be made to obtain data on the operating costs of the examined residential units and the impact of thermal upgrading on the actual heat consumption. Models will also include a more detailed subdivision into eight building types.

The topic discussed in the paper may prove useful for all participants of the real estate market in their investment decisions when purchasing real estate, or for the economic justification of outlays aiming to increase the market value of housing stock, but also in the decision-making processes of local authorities concerning the thermal upgrading of their housing stock.

\section{Reference}

Aczel, A.D. (2000). Statystyka w zarzadzaniu. Wydawnictwo Naukowe PWN, Warszawa.

Alsabry, A., Pigalski, W. \& Maciejewski, T. (2010). Teoretyczne a rzeczywiste zapotrzebowanie energetyczne na centralne ogrzewanie $i$ wentylacje mieszkań $w$ budownictwie wielorodzinnym. Przegląd Budowlany, $11,39-45$.

Bailey, M. J., Muth, R. F., \& Nurse, H. O. (1963). A Regression Method For Real Estate Price Index Construction. Journal of the American Statistical Association, 58, 933-942. https://doi.org/10.1080/01621459.1963.10480679

Bełej, M. \& Gulmontowicz, P. (2009). Analiza wpływu prac termomodernizacyjnych na wartość rynkową lokali mieszkalnych $\mathrm{w}$ zasobach wielorodzinnych. Acta Scientiarum Polonorum, Administratio Locorum, 8(3), 16.

Coulson, N. E., Dong, Z., \& Sing, T. F. (2018). Estimating Supply Functions for Residential Real Estate Attributes. The Journal of Real Estate Finance and Economics, Early View: https://onlinelibrary.wiley.com/doi/10.1111/1540-6229.12268, https://doi.org/10.1111/15406229.12268

Dydenko J. (2014). Budynki energooszczędne. Rzeczoznawca Majątkowy, 4(109), 8-17.

Directive 2012/27/EU of the European Parliament and of the Council of 25 October 2012 on energy efficiency, amending Directives 2009/125/EC and 2010/30/EU and repealing Directives 2004/8/EC and 2006/32/EC Text with EEA relevance., 65.

Directive 2010/31/EU of the European Parliament and of the Council of 19 May 2010 on the energy performance of buildings (recast)

Dzieżyc, H., Foryś,I., Kazak, J. \& Szewranski Sz. (2018). Indicator- Based Analysis of Socially Sensitive and Territorially Sustainable Development in Relation to Household Energy Consumption. 17th International Scientific Conference Engineering for Rural Development Energineering for Rural Development, Jelgava, 23-25.05.2018. 
Europejskie Standardy Wyceny - ESW. (2016). The Europem Group of Valuere's, PFSRzM, Siedlce.

FORYŚ, I. (2006). Opłacalność procesów termomodernizacyjnych na przykładzie spółdzielczych zasobów mieszkaniowych. Studia i Materiały TNN, 12(1), 48-56.

FORYŚ, I. \& NOWAK, M. (2012). Spótdzielnia czy wspólnota. Poltext, Warszawa.

FORYŚ, I. (2013). Społeczno-gospodarcze determinanty rozwoju rynku mieszkaniowego w Polsce. Ujęcie ilościowe. Wydawnictwo Naukowe Uniwersytetu Szczecińskiego, Szczecin.

Foryś, I. \& Putek-Szeląg, E. (2018). A non-classical model of mass valuation of agricultural property. Real Estate Management and Valuation, 26(4), 2-12.

Gnat, S. (2010). Wykorzystanie metod badań operacyjnych w modelowaniu wpływu podatku katastralnego na sytuację finansową gminy. PhD dissertation, WNEiZ Uniwersytet Szczeciński.

Grabiński, T., Wydymus, S. \& Zeliaś A. (1982). Metody taksonomii numerycznej w modelowaniu zjawisk społeczno- gospodarczych. PWN, 73-105.

Hozer, J., Foryś, I., Zwolankowska, M., Kokot, S. \& Kuźmiński W. (1999). Ekonometryczny algorytm masowej wyceny nieruchomości gruntowych. Prace KEiS, Stowarzyszenie Pomoc i Rozwój.

Kazak, J. (2018). The use of a decision support system for sustainable urbanization and thermal comfort in adaptation to climate change actions-the case of the Wroclaw Larger Urban Zone (Poland). Sustainability, 10(4), 1083. https://doi.org/10.3390/su10041083.

Kendall, M.G. (1948). Rank Correlation Methods, Charles Griffin \& Company Limited, London.

Korona, L. (2000). Energochtonność eksploatacyjna budynków mieszkalnych w zależności od zakresu działań termomodernizacyjnych, Konferencja Naukowo-Techniczna Politechniki Śląskiej, Gliwice, 1-6.

Korzeniewski, W. (1980). Normatyw urbanistyczny i mieszkaniowy 1974. Informator, Wydawca Centralny Ośrodek Informacji Budownictwa, Warszawa.

Kułaga, K. (2017). Zużycie energii w budynkach mieszkalnych w UE w latach 2000-2014. Inżynier Budownictwa, 2, 30-33.

Lis, Ch. (2005). Ekonometryczne modele cen transakcyjnych lokali mieszkalnych. Zeszyty Naukowe Uniwersytetu Szczecińskiego, 415, Prace Katedry Ekonometrii i Statystyki, 16, Szczecin.

Putek-Szeląg, E. (2004). Zastosowanie metod statystycznych w masowej wycenie gruntów rolnych na terenach niezurbanizowanych województwa zachodniopomorskiego. Rozprawa doktorska, WNEiZ Uniwersytet Szczeciński, Szczecin.

Putek-Szeląg, E. \& Ziembicka, B. (2016). Analiza wpływu przeprowadzenia termomodernizacji na cenę lokali mieszkalnych na przykładzie budynku z wielkiej płyty na szczecińskim rynku nieruchomości. Studia i Prace WNEiZ Uniwersytet Szczeciński, 45(1), 409-418.

Regulation of the Council of Ministers of 29 June 2005 on universal property taxation Dz.U. of 2005, No 131, item 1092.

Regulation of the Minister of Infrastructure and Development of 27 February 2015 on determining the energy performance of a building or part of a building, and energy performance certificates, Dz.U. 2015, item 376, as amended.

Sujkowski, Z. (2014). Ocena efektywności energetycznej budynków na przykładzie spółdzielni mieszkaniowej. Rzeczoznawca Majatkowy 4(109), 22-32.

Act of 7 July 1994 Building Law, uniform text Dz.U. 1994 No. 89, item 414, with amendments

Act of 21 August 1997 on real estate management, Journal of Laws of 2018, item 2204, as amended.

www.miir.gov.pl/strony/zadania/budownictwo/charakterystyka-energetyczna-

budynkow/efektywnosc-energetyczna-budynku/

Xie, J. (2018). Who Is "Misleading" Whom in Real Estate Transactions? Real Estate Economics, 46(3), 527-558. https:// doi.org/10.1111/1540-6229.12196

Ziembicka B., 2016, The influence of the technical condition of a building on the property's market value, Folia Oeconomica Stetinensia, Vol. 16(1), Wydawnictwo Naukowe Uniwersytetu Szczecińskiego, Szczecin, 197-207.

Zheng, S., Cao, J., Kahn, M. E., \& Sun, C. (2014). Cite as Real Estate Valuation and Cross-Boundary Air Pollution Externalities: Evidence from Chinese Cities. The Journal of Real Estate Finance and Economics, 48(3), 398-414. https:/ / doi.org/10.1007/s11146-013-9405-4

The project is financed within the framework of the program of the Minister of Science and Higher Education under the name "Regional Excellence Initiative" in the years 2019-2022, project number 001/RID/2018/19, the amount of financing PLN 10,684,000.00. 